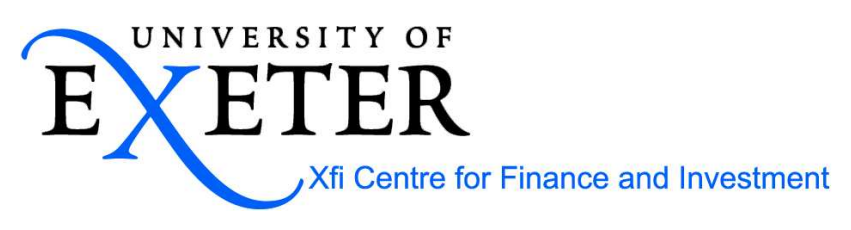

CHRISTINA DARGENIDOU, STUART MCLEAY
AND IVANA RAONIC

\title{
EXPECTED EARNINGS GROWTH AND THE COST OF CAPITAL: AN ANALYSIS OF ACCOUNTING REGIME CHANGE IN THE EUROPEAN FINANCIAL MARKET
}

\author{
September 2006
}

Paper Number: 06/12

This study focuses on the relation between the cost of equity capital and earnings expectations when the properties of accounting that determine earnings vary across different regulatory regimes. More particularly, it addresses the European setting where different types of GAAP regime have continued to function in the presence of the gradual harmonization of the underlying legal framework, and where the adoption of internationally recognised accounting standards by certain firms has anticipated the requirement for International Financial Reporting Standards. On the basis of estimates of the cost of equity that are implied by analysts' earnings forecasts, the paper provides evidence that financial market integration may have already contributed to mitigating the economic consequences of accounting diversity, and that switching to IFRS could have a short lived impact on capital markets. Moreover, based on firm level transparency and disclosure rankings provided by Standard and Poor's, it is shown how the quality of financial reporting conditions the implied cost of equity under different GAAP.

Key words: Abnormal earnings growth; Analysts' forecasts; Cost of capital; Harmonization; International financial reporting standards; Transparency and disclosure.

Stuart McLeay (s.j.mcleay@bangor.ac.uk) is a Professor at the University of Wales Bangor, and Christina Dargenidou a research associate, Xfi Center for Finance and Investment, University of Exeter, Exeter EX4 4ST, UK (c.dargenidou@exeter.ac.uk) and Ivana Raonic is a lecturer at Cass Business School, City University in London. 
This study considers whether differences between accounting regimes lead to biased expected earnings that may have cost of capital effects. The study focuses on the European setting where different standard setting authorities have continued to function in the presence of the gradual harmonization of the underlying legal framework. The recent requirement for the application of IFRS (International Financial Reporting Standards) by listed firms from 2005 onwards marks a major step in the integration process. The paper assesses the available evidence on the impact of local GAAP (Generally Accepted Accounting Principles) on the cost of equity capital in Europe in the period leading up to the regulatory changes that are now under way, and provides preliminary evidence on the effect of the voluntary pre-adoption of international standards.

Ideally, allowing for risk and growth factors, investors should be able to see through any bias arising from GAAP differences and make appropriate adjustments to the forward earnings yield, i.e., the ratio that relates expected earnings to the current price. Basically, comparability of forward earnings yields requires that any bias in forthcoming earnings will reverse in subsequent years so that the accounting method that is used should not affect intrinsic value estimates. On the other hand, the inability of investors to fully restore the effects of the bias in expected earnings would lead to earnings yields that are not comparable and prices that are not set in a homogeneous way.

It is usual to determine the share price as the present value of future cash flows, consisting of the dividends that are expected per share and the price to be received when the share is sold. However, the price at the end of the holding period depends in 
turn on dividends expected after that date. Therefore, in the most basic valuation model, an infinite stream of expected dividends values the share as follows:

$$
P_{0}=d_{1}(1+r)^{-1}+d_{2}(1+r)^{-2}+\ldots=\sum_{t=1}^{\infty} d_{t}(1+r)^{-t}
$$

where $d_{t}$ is the dividend per share in each future period $t, r$ is the cost of capital and $P_{0}$ is the current share price.

Ohlson and Juettner (2005) show that, for any sequence of numbers $\left\{y_{t}\right\}$ that satisfy $(1+r)^{-t} y_{t} \rightarrow 0$ as $t \rightarrow \infty$, then

$0=y_{0}+(1+r)^{-1}\left[y_{1}-(1+r) y_{0}\right]+(1+r)^{-2}\left[y_{2}-(1+r) y_{1}\right]+\ldots$

and, therefore, by combining equations (1) and (2),

$P_{0}=y_{0}+\sum_{t=1}^{\infty}(1+r)^{-t}\left(y_{t}+d_{t}-(1+r) y_{t-1}\right)$

where $y_{t}$ can be any number that satisfies condition (2). This is a general formula for any valuation model that is derived from (1). For example, if $y_{t}$ equals 0 , then (3) transforms to the dividend discount model (2). If $y_{t}$ equals book value per share $b_{t}$, then (3) transforms instead to the residual income model. ${ }^{1}$

$$
P_{0}=b_{0}+\sum_{t=1}^{\infty}(1+r)^{-t}\left(e_{t}-r \cdot b_{t-1}\right)
$$

\footnotetext{
${ }^{1}$ For a detailed presentation of the unified valuation framework presented here, see also Gode and Ohlson (2006).
} 
On the other hand, if $y_{t}$ is capitalised expected earnings ${ }^{2}$, where

$y_{t}=\frac{e_{t+1}}{r}, \quad t=0,1,2, \ldots$

then condition (2) still holds but (3) transforms to the pricing model that informs the analysis in this paper:-

$P_{0}=\frac{e_{1}}{r}+\sum_{t=1}^{\infty}(1+r)^{-t} \cdot z_{t}$

where $z_{t}=\frac{1}{r}\left[e_{t+1}+r \cdot d_{t}-(1+r) e_{t}\right], \quad t=1,2, \ldots$

The $z$ sequence represents capitalised expected abnormal earnings, that is the surplus over the normal earnings expected from the reinvestment of the previous period's earnings. In this formulation, the dividend irrelevancy property is satisfied by adding the term $r \cdot d_{t}$ to represent the foregone investment opportunity at the cost of capital $r$ of having paid dividends $d_{t}$. Assuming that abnormal earnings grow in time at a rate $(1+g)$, where $r>g \geq 0$, then (5) can be summarized as the abnormal earnings growth model, as follows:

$P_{0}=\left[\frac{e_{1}}{r}+\frac{e_{2}+r \cdot d_{1}-(1+r) e_{1}}{r \cdot(r-g)}\right]$

Based on (6), Easton (2004) argues that, if the forecast of next period's accounting earnings is equal to the equilibrium economic income (the product of the expected rate of return and the beginning of period price), accounting earnings are sufficient for valuation by definition, and also that the forward earnings yield is equal to the cost of

2 The focus on expected earnings is consistent with Modigliani and Miller (1961) who suggest that equity values are determined by the earnings power of the firm's assets and its investment policy, and not by how the earnings are distributed. 
equity. However, if $e_{1}$ does not equal economic income (as is mostly likely to happen, due to the conservative nature of accounting systems which defer the recognition of positive value shocks), then valuation based on accounting earnings requires forecasts beyond the next period. ${ }^{3}$ Therefore, as made clear by Easton (2004), the abnormal earnings growth in (6) $\frac{e_{2}+r \cdot d_{1}-(1+r) e_{1}}{r(r-g)}$ reflects the fact that differences between accounting earnings and economic income in any one period must be captured in the accounting earnings of other periods.

Multiplying both sides of equation (6) by the cost of capital, it is evident that the difference between the equilibrium economic income $r \cdot P_{0}$ and accounting earnings $e_{1}$ is determined by both the short term growth in accounting earnings and the long term growth in abnormal earnings, as follows:

$$
r \cdot P_{0}=e_{1}+\frac{e_{2}+r \cdot d_{1}-(1+r) e_{1}}{(r-g)}
$$

Whilst abnormal earnings grow at the long term rate $g$, short term growth in earnings is incorporated as the change from $e_{1}$ to $e_{2}$, adjusted for the previous period's retained earnings reinvestment. Although the latter suggests that dividend policy is irrelevant in the short term, equation (7) implies nevertheless that, given a sufficiently generous dividend policy, $e_{t} / e_{t-1} \rightarrow 1+g$ as $t \rightarrow \infty .{ }^{4}$ In other words, as Ohlson and Juettner

\footnotetext{
${ }^{3}$ See Pope and Walker (1999) and Beaver and Ryan (2005) for a more thorough analysis of accounting conservatism. The difference between economic and accounting earnings stems from under-recognised positive value shocks, which are the source of expected accounting earnings growth.

${ }^{4}$ A sufficiently generous dividend policy would be a payout ratio that exceeds ( $\left.\mathrm{r}-\mathrm{g}\right) / \mathrm{r}$. In the long term, it can be expected that, as the competitive advantage of the firm fades away, it would be reasonable to assume an almost full payout policy as it is implausible that earnings will be re-invested in the firm for ever. Consistent with the development of these arguments, the growth rate $g$ is assumed in Ohlson and Juettner-Nauroth (2005) to approximate an economy-wide growth rate.
} 
(2005) and Ohlson and Gode (2006) show, the growth in accounting earnings decays in the long term towards the abnormal earnings growth rate $g$.

\section{ACCOUNTING DIVERSITY AND THE FORWARd EARNINGS YIELD}

Equation (7) scaled by $P_{0}$ shows that the forward earnings yield $e_{1} / P_{0}$ will consist of the cost of equity capital, i.e., the risk free rate $r_{f}$ plus the risk premium $r-r_{f}$, less the (discounted) abnormal earnings yield, as follows:

$$
\frac{e_{1}}{P_{0}}=r_{f}+\left(r-r_{f}\right)-\frac{\left(e_{2}+r \cdot d_{1}-(1+r) e_{1}\right) /(r-g)}{P_{0}}
$$

Equation (8) shows that any cross-country variation in the forward earnings yield must be induced by three factors - the variation in country specific risk free rates, the variation in risk premia and the variation in the abnormal earnings yield, where the latter corrects the initial understatement of $e_{1}$ when accounting earnings are less than economic income.

In integrated financial markets, risk is likely to be priced homogeneously, as market mechanisms are more able to eliminate pricing differences through arbitrage. Thus, integrated financial markets are likely to be characterised by little variation in country-specific risk free rates and risk premia, if sector effects remain constant across the countries involved. This is not likely to happen with respect to the forward earnings yield as long as accounting is not harmonised, or to be more precise, when there are still systematic differences across countries in the recognition of value shocks in accounting earnings. 
Recent research has shown that different accounting systems bring about different speeds of recognition of value shocks in accounting earnings, leading to country specific variability in the extent to which accounting earnings differ from economic earnings. ${ }^{5}$ Based on equation (7), which expresses the difference between economic income and accounting earnings in terms of the abnormal earnings yield, our proposal is that variability in the speed of recognition of value shocks in accounting earnings induces significant country variation in the abnormal earnings yield. ${ }^{6}$

In contrast to the diversity in accounting rules and regulations that has held sway over European markets until recently, the new phase of standardization that is currently under way is based on the adoption of International Financial Reporting Standards by all listed companies in the EU from 2005 onwards. In principle, this should lead to similarity in the recognition of value shocks when the circumstances in which firms operate are the same. This would be the case, for example, if firms operate in the same industry, even though they may be registered in different jurisdictions. Thus, when accounting is harmonised and financial markets are integrated, the variation in the earnings yield as described in (8) would be attributed to sector effects in both the risk premium and abnormal earnings yield, and country effects would be insignificant. Furthermore, earnings yields would be directly comparable across countries, and such comparability would only require knowledge

\footnotetext{
5 See Ball, Kothari and Robin (2001), Giner and Rees (2001), Garcia Lara and Mora (2004) and Raonic, McLeay and Asimakopoulos (2004) for empirical evidence on the varying speed of value shock recognition in accounting earnings internationally.

${ }^{6}$ Note that, under converging economies and integrated markets, the country-specific variation in $r$ and $g$ should not influence country-specific variation in the abnormal yield. In the context of (8), this variation is likely to be driven mostly by abnormal earnings at time $t=2$ (which is dividend policy irrelevant, and therefore country-specific factors in dividend policy should also be of no consequence). Ideally, an examination of abnormal earnings at time $t \geq 3$ would provide further insight into the way in which accounting earnings catch up with economic earnings in different countries and a better assessment of country variation at different points on the forecast horizon.
} 
of industry-specific practices with respect to the recognition of value shocks in accounting earnings. ${ }^{7}$

\section{RESEARCH DESIGN}

The influence of harmonization is examined by modelling systematic effects in the forward earnings yield and its components that were described in equation (8). More specifically, the firm panel data is cross-categorised by country and sector in order to assess the relevant influence of these factors on the forward earnings yield, the risk premium and the abnormal earnings yield. ${ }^{8}$ The preferred regression approach is one that allows for observations that are independent across groups but not within groups as this provides a statistical test for the significance of country and sector effects that is robust with respect to correlation within panels. The regression is estimated as

$$
E P_{i}=\mu+\alpha_{s}+\beta_{c}+\gamma_{t}+M C_{i}+e_{i}
$$

where $E P_{i}$ denotes the forward earnings yield for firm $i$, and where $\mu$ is the average earnings yield across all firms and all years, with sector effects $\alpha_{s}$, country effects $\beta_{c}$ and time effects $\gamma_{t}$. Market capitalization $M C_{i}$ is also included in the model as a covariate that controls for size effects.

\footnotetext{
${ }^{7}$ Land and Lang (2002) examine cross-country differences in trailing earnings yields, finding that they have become more similar over time. However, as Yee (2004) explains, the forward earnings which are employed in the present study demand less of accrual accounting than trailing earnings, and are more accurate equity valuation attributes.

${ }^{8}$ Estimation of the implied cost of equity capital and risk premia in the context of the Ohlson-Juettner (2005) model has already been reported in the accounting research literature, the estimation being substantiated by reasonable association with various risk proxies - see Gode and Mohanram (2003) and Botosan and Plumlee (2005). The cost of equity capital is also implied by other equity valuation models, and may be estimated accordingly. The research design in this paper is developed from the analysis in equations 6-8, this particular model being particularly appropriate for international comparison as it is not subject to dirty surplus biases - see Fen, Jorgensen and Yoo (2004) for a discussion of the impact of dirty suplus accounting on the implied cost of capital.
} 
The same panel data structure is employed to assess country and sector effects in the risk premium, that is to say with $r-r_{f}$ as the dependent variable in (9) instead of $E P$. Assuming that there is little variation in risk free rates, which has been the case in Europe in recent years, the main driver for systematic variation in the cost of capital would be country effects in the risk premium. Evidence that risk premia have converged is provided when the $\beta_{c}$ in (9) are jointly insignificant after controlling for sector effects. ${ }^{9}$ It is worth noting also that, if the cross-country variation in earnings yields remains significant even when the risk premia have converged, this could imply that accounting diversity is not an impediment to financial market integration. To the extent that financial market integration coincides with economic convergence, there should be less systematic variation in the abnormal earnings yield. Substituting the abnormal earnings yield as the dependent variable in (9) instead of $E P$, the joint significance of $\beta_{c}$ is expected to decrease although it will not be removed entirely whilst accounting harmonization remains incomplete.

Overall, it is expected that, given the degree of European financial market integration in recent years, cross-country variation in the forward earnings yield is likely to be driven to a great extent by the remaining constraints on accounting harmonization that are reflected in systematic differences across jurisdictions in the rate of recognition of economic income.

\footnotetext{
${ }^{9}$ In their analysis of equity market returns in Europe, Adjaouté and Danthine (2004) show a diminishing role for geographical diversification as financial integration has deepened, and an increasing role for industrial diversification. In this respect, therefore, sector effects are expected to determine the implied cost of equity capital to an extent that is greater than country effects.
} 


\section{The USe of Analysts' Forecasts as a Proxy for Earnings Expectations}

An important issue underlying the estimation of (9) is that investors' expectations are unobservable, and analysts' forecasts are used instead as a proxy. The main body of literature on analysts' forecasts shows them to be both biased and inaccurate. However, more recent advances show that the evidence on inaccuracy is largely due to earnings' management practices rather than to analysts' own irrationality (Abarbanell and Lehavy, 2003). Basu and Markov (2004) also reject the prior evidence on analysts' irrationality, explaining that the tests first reported in the study by De Bont and Thaler (1990) relied crucially on the nature of the forecast error that analysts aim to minimise. ${ }^{10}$ On the other hand, Helbok and Walker (2004) argue that analysts are aware of the conservative nature of reported earnings and its influence on future earnings. They show that analysts revise current period forecasts to reflect value shocks in an asymmetric manner, and one period ahead forecasts to account for the reversal in the over/under recognition of current news in reported earnings. Consequently, earnings forecasts that are produced at the time of the announcement of previous year earnings are likely to appear as unbiased when value shocks during the current fiscal year are positive (because positive shocks are hardly recognised in the

\footnotetext{
${ }^{10}$ Other research shows that analyst job turnover is associated with the mean absolute error of their forecasts (see Mikhail, Walther and Willis, 1999 and Hong and Kubik, 2003). With respect to analysts' incentives to generate business by means of optimistic forecasts, Irvine (2004) shows that individual analysts' forecast errors are not associated with increased trading by brokerage firms; instead, it is positive stock recommendations that generate trading commissions. Lin and McNichols (1998) find no evidence that affiliated analysts' earnings forecasts, either for the current year or for one year ahead, exhibit greater optimism than do unaffiliated analysts' forecasts. However, both Lin and McNichols (1998) and Dechow, Hutton and Sloan (2000) report greater optimism with respect to long term earnings growth, which is more consistent with optimistic recommendations. The drawback in these studies however is that the association between affiliated analysts and optimism is observed under the special circumstances of an equity offering, where substantial underwriting fees are involved (see Dechow, Hutton and Sloan, 2000, on the positive association of underwriting fees and optimism).
} 
current year), and optimistic when the news during the year is negative (because negative value shocks are recognised to a greater extent than positive shocks).

The second potential criticism with respect to the use of analysts' forecasts as proxies of earnings forecasts in the context of a comparison of local accounting regimes is that forecasts are based on adjusted reported earnings, and, as a result of this adjustment, they may not necessarily reflect international differences in accounting. Analysts' forecasts are indeed free of extraordinary items that could contribute to country variation in the earnings yield. However, as these items are transitory, this does not affect the evidence from the present study, which focuses on core earnings. $^{11}$

\section{ANALYSIS OF LOCAL GAAP REGIMES}

The sample consists of firms reporting under their local GAAP, originating from 16 European jurisdictions (Austria, Belgium, Denmark, Finland, France, Germany, Greece, Italy, Ireland, Netherlands, Norway, Portugal, Spain, Sweden, Switzerland and UK). Not all of the countries involved are member states of the EU, but Norway and Switzerland are included due to their close economic ties with the rest of Europe. The period examined in the study is from 1994 to 2003, and the sample comprises both active firms at the census date and inactive firms that ceased operations during the period. It should be noted that, before 1994, coverage of analysts' forecasts for these markets was not representative, especially with respect to Ireland and Greece.

\footnotetext{
${ }^{11}$ It should be noted that the reported earnings figure is not a good proxy for earnings expectations since it includes value shocks that are not relevant to the current price. The extent to which we still observe country variation, even with smoothed earnings estimates, implies that sophisticated market participants will perceive accounting in the European market as not yet fully harmonised.
} 
Two sub-periods are taken into consideration in the analysis, as events suggest that the effects of financial integration are likely to have accelerated since 2000 .

Annual data on market capitalization, the dividend payout ratio, and the book to market ratio are drawn from the Worldscope database in Thomson Financials. The dividend payout ratio is averaged over the three years prior to the relevant point estimates and then multiplied by the earnings expectation one year ahead to obtain an estimate of the forthcoming year's expected dividends. Earnings expectations are proxied by IBES median forecasts. An important issue that arises when combining data from various databases concerns the different adjustment factors employed to render earnings per share and prices comparable over time, mostly by adjusting for capital issues and stock splits. To circumvent this problem, earnings per share forecasts in IBES are multiplied by the number of shares provided in IBES and then divided by market capitalization to calculate $E P$.

The sample is restricted to firms that report with a December year end. As at the end of December, the current forecast is for the accounting year ending on that date. The model requires earnings forecasts for the year following the current forecast and for the year after that. For these predictions of forthcoming earnings, the median of December forecasts is employed for each of the two accounting years ending 12 months and 24 months later. Appropriate controls have been taken to ensure that the forecasts satisfy the 12 and 24 months year end. Furthermore, firms whose one year ahead earnings forecast and growth is negative are excluded since it is possible neither 
to reinvest negative earnings nor to perpetuate negative earnings growth. ${ }^{12}$ For the primary analysis, these specifications yielded the cost of equity for 11,395 firm-year observations that are designated by Worldscope as reporting under local GAAP. ${ }^{13}$

Finally, in order to infer the cost of equity capital from earning expectations in analysts' forecasts, the present study employs the Ohlson and Juettner (2005) pricing methodology in (6), and for the parameter $g$, which represents an economy wide growth factor, we make three different assumptions in order to examine the sensitivity of our inferences to the growth rates employed in the estimation of the implied cost of capital. First, $g$ is approximated by the risk free rate, and second by expected inflation. In the latter case, Gode and Mohanram (2003) suggest that an approximation can be obtained by deducting the long term real growth of the economy (about $3 \%$ in the US) from the risk free rate, a method adopted by Cheng et al. (2003) in an international context. In this paper however, following Leuz and Hail (2005), we base our second measure on the Consumer Price Index, and more specifically the average of the two years ahead annual CPI growth rate. In the third case, the hypotheses are tested under the assumption that $g=0$. Risk free rates (i.e, the ten year government bond yield) and CPI data are extracted from Datastream.

\footnotetext{
${ }^{12}$ A potential remedy to this limitation is to replace the short term growth in earnings with the average growth in the medium term. This strategy however would compromise considerably the representation of smaller firms and those from smaller markets.

${ }^{13}$ Out of 16,080 firm-year observations that satisfied the December year-end criterion, with earnings forecasts available for both one and two years ahead, together with the necessary information on the respective number of shares and on whether the firm was reporting under either local, IAS or US GAAP, 759 were deleted because earnings one year ahead were negative. A further 1,336 were deleted because the change in earnings between one and two years ahead was negative. With respect to the firm-years under local GAAP, out of the remaining 12,462, another 1067 observations were deleted as there were no available data on Worldscope or a computation of the cost of capital was impossible. As to the IAS and US GAAP, samples vary depending on the research design of the test where these observations are employed.
} 
Estimates of the abnormal earnings yield and the risk premium under these three assumptions are presented on a country, sector and yearly basis in Table 1, together with details of the risk free rate and the forward earnings yield. The abnormal earnings yield represents the expected earnings growth that is priced in the earnings yield. Thus, low earnings yields due to conservatism should also be characterised by higher abnormal earnings yield. This is the case for Germany and Italy, for example, which have the lowest earnings yields among the 16 countries covered by Panel A ( 0.0548 for Germany and 0.574 for Italy), but also a relatively high level of abnormal earnings yield (eg. 0.0711 and 0.779 , when government bond yield is taken as the proxy for long term growth). On the other hand, the earnings yields in Ireland and the Netherlands are the two highest in the sample $(0.0847$ for Ireland and 0.885 for the Netherlands), whilst the respective abnormal earnings yields are the lowest under all growth assumptions (eg. 0.0421 and 0.426 when $g$ is set at the government bond yield). The trade-off between the earnings yield and the abnormal earnings yield at the country level is evident in Figure 1, which illustrates the inverse relationship graphically. On the other hand, this trade-off does not seem to be present at the industry level, as the descriptive statistics in Panel B of Table 1 reveal in all sectors except one. ${ }^{14}$ The absence of such effects at the sector level is also illustrated in Figure 1, thus supporting the hypothesis that the differences in degrees of value recognition in the earnings yield and the abnormal earnings yield seem to be driven primarily by accounting diversity across countries rather than by industry specific characteristics.

\footnotetext{
${ }^{14}$ The exception is the technology sector, a special case which was greatly influenced by the internet bubble that started in the mid 1990s. At this time, investors and analysts may have expected more growth in perpetuity rather than in the immediate future and therefore would have incorporated a greater portion of the value driver in forecasted abnormal earnings growth than in forward earnings.
} 
Finally, it can be seen in Panel C of Table 1 that the trade-off between earnings yields and abnormal earnings is not present on a yearly basis, since the country effects (which are considered to drive this) and the sector effects are aggregated. ${ }^{15}$ Perhaps the most important evidence in Panel $\mathrm{C}$ is the decreasing risk free rate, the long term government bond yield falling as one would expect in integrating financial markets. ${ }^{16}$

\section{Empirical results}

The first set of tests examines the significance of sector and country effects in the earnings yield. These tests are conducted separately for the sub-periods 1994-2000 and 2001-2003 in order to capture any time variation that could be attributed to the increased integration of European financial markets, particularly the partial integration stemming from the introduction of a common currency in a number of the countries involved.

It is expected that the sector effect would contribute most to the variation in the earnings yield and that the country effect would add relatively little explanatory power over and above the sector effect. The results reported in Table 2 show the outcome of introducing sector effects first and then adding country effects, and also vice versa. When controlling for each effect in this way, it is found that both are present and significant in each period. The R-squareds reported in Table 2 shows that sector effects alone account for $16.12 \%$ of the variation in the forward earnings yield in the first period and $13.76 \%$ in the second period, and that country effects alone

\footnotetext{
${ }^{15}$ It can be seen that the number of observations falls in later years. This is explained by the increasing number of firms that have switched to IAS or US GAAP, especially in Germany after the introduction of the New Market.

16 The standard deviation of the risk free rate in the present sample decreases from $1994(0.0163)$ to 2003 (0.0039).
} 
account first for $15.34 \%$ and then for $10.42 \%$. It is notable however that the incremental explanatory power that arises from adding the country effects drops from $4.57 \%$ for the early years to $3.69 \%$ after 2000 , whereas the addition of sector effects causes the incremental explanatory power to increase between the two periods from $5.35 \%$ to $7.03 \%$. Indeed, given the lower joint significance of country effects after 2000 (F test: 7.39 versus 16.68), this warrants a further examination of the country and sector effects in the different components of the earnings yields.

A similar analysis of sector and country effects in the estimated risk premium and in the abnormal earnings yield is also presented in Table 2, under each of the three growth assumptions discussed earlier. With regard to the risk premium, sector effects appear to explain most of the variation and, although significant when taken alone, this time country effects appear to add little to the overall explanatory power (the incremental $\mathrm{R}^{2}$ through 2000 is $1.04 \%, 1.02 \%$ and $1.20 \%$ assuming long term growth respectively at the government bond rate, the inflation rate and at zero, and after 2000 it is $0.56 \%, 0.64 \%$ and $0.59 \%$ ). The main insight is that, having established that there is significant country variation at all times in the earnings yield, i.e., that accounting diversity remains present throughout, the risk premia on the other hand appear to be unaffected by accounting diversity, especially in the later years. In fact, country effects have no joint significance in the risk premium after 2000 (F test: 1.30, 1.26 and 1.21 under each of the three growth assumptions). Bearing in mind that the estimated risk premia are constructed by means of accounting earnings expectations, this lends strong support to the inferences with respect to accounting harmonization. Whatever country-driven variation there might be in accounting earnings expectations, its influence appears to have been mitigated, as it should be if 
accounting diversity has few economic consequences. This result corroborates the general inference drawn from Table 1, and illustrated by Figure 1, that accounting diversity drives the cross-country differences in the trade-off between risk premium components. Here, it is evident from Table 2 that cross-country differences indeed disappear once accounting diversity has been minimised.

Finally, since we do not expect significant country effects in risk premia within relatively integrated markets, and this study shows that recently they no longer have explanatory power beyond sector effects, then it is consequent that the persistent country effects detected in the earnings yields are mostly driven by international differences in the rate of recognition of economic income. These differences are not expected to disappear until there is full harmonization between local accounting regimes in Europe. This inference is also supported by the analysis of the abnormal earnings yield, where the lower joint significance in the second period (e.g., F test when growth is set at the government bond yield: 5.36 versus 18.10) suggests that country effects in abnormal earnings yield, although declining, have not been eliminated, reflecting the earlier results with respect to the forward earnings yield.

\section{The EConomic Consequences of ACCOUnting Transition}

International Financial Reporting Standards, and US GAAP, are commonly acknowledged to impose a greater level of disclosure than is generally required by other sets of accounting rules and regulations (such is the argument for Germany, for example -- see Leuz, 2003). Recently, national regulatory bodies in Europe have been moving their own rules towards IFRS in order to enable the more general transition in 
2005. Moreover, certain firms in Europe have pre-empted the transition by reporting already under IFRS (and previously under IAS), and, in some cases, under US GAAP. In this study, it is argued that the main costs of a transition to IFRS or US GAAP are firm specific and are associated with the level and type of disclosure before switching. The greater the disclosure before the transition, and the closer the accounting policies to those set out in IFRS or US GAAP, the easier it is for market participants to connect the past with the future and hence to be able to unravel the accounting impact on future cash flows. Accounting standardization per se does not have economic consequences in integrated financial markets, as shown in the previous section. Thus, the transition to another set of accounting standards is expected to have economic consequences insofar as prior disclosure is not sufficient to inform market participants about the impact of accounting change. However, the costs involved are likely to be temporary and to dissipate following transition, with the economic consequences for any firm being more pronounced in the early stages of adoption, although this would all depend not only on disclosure levels but also on the set of standards that is adopted. As Barth, Clinch and Shibano (1999) demonstrate, adherence to a set of increased visibility GAAP can lead to market prices that more accurately reflect true value and a reduced cost of capital.

With respect to the estimation of the effect of standard switching, the methodology followed is similar to that described above for the examination of local GAAP effects. We focus now, however, on the economic consequences of the transition by examining the risk premium associated with standard switching and its subsequent 
evolution, conditional on the prior disclosure level as represented by the firm's market capitalization before the transition. ${ }^{17}$

With respect to the risk premium $\left(r-r_{f}\right)$, the following regression is run:

$$
\left(r-r_{f}\right)_{i}=\mu+a_{S}+\beta_{c}+\boldsymbol{\delta}\left[\begin{array}{c}
D_{G A A P} \\
M C_{i} \\
D_{G A A P} \times M C_{i}
\end{array}\right]+\gamma_{t}+e_{i}
$$

where $D_{G A A P}$ is a dummy variable that distinguishes whether or not the accounting standards used by the firm in drawing up its financial statements are local or international (IAS/IFRS or US GAAP), taking the value of zero for those years in which the firm reports under the local rules and the value of one otherwise. The dummy variable is interacted with the prior level of disclosure, proxied by the firm's market capitalization $M C_{i}$, in order to control for the extent of pre-disclosure that prepared the ground for standard switching, with the respective main effects and interaction effects given by the inverse of the vector of coefficients $\boldsymbol{\delta}{ }^{18}$ The sector, country and time period controls are also important in this respect, as evidence on the economic consequences of standard switching might be biased by particular sectors, or by adopters of international standards that originate in local GAAP regimes which

\footnotetext{
${ }^{17}$ Market capitalization is kept constant across years for each firm, at a value corresponding to the firm's market capitalization in the year immediately prior to the transition. The idea of expressing predisclosure (i.e., voluntary information release) as a function of market capitalization dates back to Atiase (1985). More recently, Leuz and Verrechia (2000) and Leuz (2003) also argue that larger firms tend to disclose more, and Cuijpers and Buijink (2005) employ market capitalization as a proxy for firm level disclosure in a study of voluntary switching to foreign GAAP.
}

${ }^{18}$ Vectors $\boldsymbol{\delta}$ and $\boldsymbol{\lambda}$ in equations (10) and (11) correspond to coefficients $\delta_{n}$ in $\left[\begin{array}{l}\delta_{1} \\ \delta_{2} \\ \delta_{3}\end{array}\right]$ and $\lambda_{n}$ in $\left[\begin{array}{l}\lambda_{1} \\ \lambda_{2} \\ \lambda_{3}\end{array}\right]$. 
are less harmonised internationally, or just because most of the transitions have taken place at a point in time when the risk premium is elevated.

A further test examines whether or not the economic cost of transition is a transitory phenomenon that has a more pronounced effect in the initial period of application of the new set of standards. For this purpose, $L_{G A A P}$ represents the length of the adoption period, i.e., the number of years during which the firm's financial statements have been prepared in accordance with IAS/IFRS or US GAAP. As above, this variable is also interacted with the prior level of disclosure, proxied by the firm's market capitalization $M C_{i}$, and in this case the respective main effects and interaction effects are given by the inverse of the vector of coefficients $\lambda$, as follows:

$$
\left(r-r_{f}\right)_{i}=\mu+a_{S}+\beta_{c}+\lambda\left[\begin{array}{c}
L_{G A A P} \\
M C_{i} \\
L_{G A A P} \times M C_{i}
\end{array}\right]+\gamma_{t}+e_{i}
$$

The IFRS sample (107 firms) comprises mainly German, Swiss and Austrian companies but also others from Belgium, Denmark, Spain, Finland, Greece, Italy and Portugal, all of which have switched to IFRS (or previously IAS) since $1995 .{ }^{19}$ The US GAAP sample comprises only 48 firms, the majority of which originate in Germany, with others from Austria, Belgium, Switzerland, Spain, Greece, Italy and the Netherlands. The full sample includes firm-year observations for which an estimate of the cost of equity is feasible, for those firms for which there is also at least one observation of the cost of equity when they were reporting under their local GAAP. These strict criteria have generated 712 firm-year observations for firms that

\footnotetext{
${ }^{19}$ There are few cases where firms switched from IAS to local GAAP or to US GAAP (not included).
} 
opted to report under IFRS and 243 firm-year observations under US GAAP, including cost of earnings yields and cost of capital estimates before and after the switch.

\section{Empirical results}

Due to the sampling procedure, some consideration of the behaviour of the risk premium in each firm series is required in the estimation. Therefore, a cross-sectional time series linear model is fitted using feasible generalized least squares. This allows estimation in the presence of $\mathrm{AR}(1)$ autocorrelation within panels and cross-sectional correlation across panels.

Table 3, Panel A, presents the empirical evidence concerning the adoption of international standards, as set out in equation (10). With respect to the firms that opt for IFRS, such adoption appears to entail significant costs as the risk premium increases by an estimated $4.55 \%$ (the $\delta$ coefficient on $D_{G A A P}$ is significant at less than $0.1 \%){ }^{20}$ This is especially so for smaller firms, as suggested by the negative sign on the $D_{G A A P} \times M C$ interaction of the adoption dummy with market capitalization. Conversely, it may be inferred that the switch to IFRS has been less costly for firms that were already extensive disclosers. With regard to US GAAP, the estimated increase in the risk premium is at a similar level of $4.65 \%$, although this is only weakly significant (p-value: 0.014$)$ and there is no evidence of an effect of preadoption disclosure. However, insofar as the adoption of US GAAP may entail the use of a more visible set of standards and a commitment to greater disclosure, transition

\footnotetext{
${ }^{20}$ Daske (2005) provides similar evidence on the occurrence of costs due to the transition to IFRS for German companies.
} 
costs might fall quickly after the switch ${ }^{21}$. This issue is further examined by evaluating the impact of the length of experience with internationally recognised GAAP and, second, by means of a comparison of the impact of the disclosure effect on risk premia conditional on the set of standards employed.

The results in Panel B of Table 3 suggest that risk premia associated with IFRS adoption are likely to decline as the length of the period of application is extended, as suggested by the negative sign of the estimated $\lambda$ coefficient on $L_{G A A P}$ (albeit weakly significant with a $p$-value of 0.022$).{ }^{22}$ This correction is especially pronounced for firms whose disclosure level before IFRS adoption was limited, as suggested by the positive and significant coefficient on $L_{G A A P} \times M C$, the interaction between the length of the adoption period and market capitalization (p-value: 0.005$)$. Note that these firms bear larger costs of transition overall, and combining the evidence reported in the two panels it now becomes clear that this result is likely to be driven primarily by the early years of IFRS adoption. On the other hand, this correction effect will be less pronounced for those firms that incurred lower costs in the first place.

With regard to US GAAP, however, there is stronger evidence of a correction of the initial costs associated with adoption, which is suggested by the significantly negative $\lambda$ coefficient on $L_{G A A P}(p$-value $<0.001)$. Nevertheless, contrary to IFRS, the

\footnotetext{
${ }^{21}$ Bushee and Leuz (2005) demonstrate that the imposition of stricter mandated disclosure is associated with significant costs for smaller firms that have not filed previously with SEC, turning some of them towards less regulated markets. On the other hand, previous experience with SEC has significant benefits in terms of a permanent increase in liquidity and positive stock returns.

${ }^{22}$ Note that, in Panel B of Table 3, the number of firms and firm-year observations is reduced with respect to Panel A. This is due both to the research design, which in this case takes into account only the sub-sample of firms that have switched to internationally recognised GAAP, and to the use of a feasible GLS regression that excludes firms with just one available firm-year observation. A similar GLS regression, which does not take into account the autocorrelation within the firm (while allowing for heteroscedasticity), yields qualitatively equivalent results based on the same number firms as in Panel A.
} 
level of pre-adoption disclosure appears to have no effect on the decrease in the risk premia after the adoption of US GAAP, as suggested by the insignificant $\lambda$ coefficient on the interaction between $L_{G A A P}$ and $M C$ (p-value: 0.284$)$. The initial finding of (albeit weakly) significant costs associated with a switch to US GAAP appears also to be driven by the first year of transition. Note the magnitudes of $\delta D_{G A A P}$ and $\lambda L_{G A A P}$ are respectively 0.0465 and -0.0508 , whilst the corresponding estimates under IFRS are 0.0455 and -0.0130 , which implies that it takes longer for the initial transition costs to abate under IFRS.

The evidence in Table 3 suggests that, although there are costs associated with the transition to internationally recognised GAAP, these are likely to be transitory. The transitory nature of adoption costs is especially pronounced for firms characterised by limited disclosure before their switch to IFRS, and for all firms that switch to US GAAP regardless of their pre-adoption level of disclosure. It is possible that the enhanced visibility and transparency of US GAAP ensures that transition costs fade out quickly, as shown in Panel B. This issue is further examined in the following section by associating levels of disclosure with risk premia after firms have switched to foreign GAAP.

\section{TRANSPARENCY AND DisClOSURE}

The empirical evidence set out above suggests that extensive prior disclosure may decrease the costs of a switch to a new set of accounting standards in terms of the firm's risk premium. This finding is in line with evidence reported elsewhere of a 
negative relationship between disclosure and the cost of capital. ${ }^{23}$ This is because financial transparency, and timely and adequate disclosure, facilitate the external monitoring of managers, reduce the risk of expropriation from shareholders, and therefore lower the expected rate of return that investors demand on their capital. ${ }^{24}$ In this study, we posit that, as capital markets become more integrated, country-specific factors will tend to lose their importance in explaining differences between firms in the cost of equity capital. As a result, investors will rely primarily on firm level disclosure. Moreover, a firm's commitment to better disclosure and greater financial transparency will reduce information asymmetries between insiders (managers or controlling shareholders) and outsiders (minority shareholders, creditors and other stakeholders). In particular, the adoption of internationally recognised reporting standards such as IFRS or US GAAP will commit the firm to regimes that make it more difficult for insiders to conceal private control benefits from outsiders. ${ }^{25}$ Whether the reduction in information asymmetry that lowers the rate of return

\footnotetext{
${ }^{23}$ Hail (2002) shows that firms which disclose more on a voluntary basis enjoy a lower cost of capital. Further evidence of this negative relationship is provided by Botosan and Plumlee (2002) and Leuz and Hail (2003). Although public disclosure may remove uncertainty about the firm's earnings and reduce risk accordingly, this may be more than offset by increases in the cost of capital arising from more precise private information (Botosan, Plumlee, and Xie, 2004). Moreover, accounting restatements initiated by the firm's auditors, the regulatory authorities or the firm itself can lead to increases in the firm's cost of equity capital, which is consistent with lowering the perceived earnings quality of the firm and increasing investors' required rates of return (Hribar and Jenkins, 2004).

${ }^{24}$ At the country level, financial transparency is shown by Bushman, Piotroski and Smith (2004) to be higher when there is a lower risk of actions by the state that influence the required rate of return in a negative manner. Further evidence on the incorporation of market and firm information into stock prices is given in Piotroski and Roulstone (2004), and the association between the disclosure of accounting information and corporate governance systems is considered in Bushman, Chen, Engel and Smith (2004). Leuz, Nanda and Wysocki (2003) provide evidence that differences in earnings management across countries may be attributed to corporate governance mechanisms, as, in the absence of strong protection, insiders tend to use earnings management to protect their own interests by concealing firm performance from outsiders.

${ }^{25}$ Whilst US GAAP are often portrayed as the benchmark for high-quality standards and for providing relevant information to the capital markets (Levitt, 1998, McGregor, 1999), recent empirical research suggests that there is no evidence that US GAAP result in higher information quality than IAS/IFRS. Rather, it has been demonstrated that both set of standards reduce information asymmetries in capital markets equally well (and better compared to the local GAAP) once they are embedded in the same regulatory environment (Leuz, 2003).
} 
required by equity capital providers is better secured by adoption of IFRS or US GAAP is an empirical question. Consequently, this last section of the paper investigates the magnitude of the effect of firm level disclosure on the required rate of return in terms of firm's risk premium conditional upon the firm's choice between the two different sets of internationally recognised accounting standards.

As a measure of firm level disclosure practices, we use the scores constructed in Standard and Poor's Financial Transparency and Disclosure (2002) survey. The survey focuses on a wide range of attributes and their coverage in key public documents released by companies. These attributes are grouped into three broad categories, concerning: (a) ownership structures and investor rights, (b) financial transparency and (c) board and management structure and process. These are further broken down into twelve sub-categories, and cover seventy two different topics in total. A score of 1 is assigned to a firm for each attribute that is found to be present and 0 if otherwise. Panel A of Table 5, which shows the median transparency and disclosure score across countries and sectors, and also with respect to the accounting standards adopted by the firms involved. These indicate a far wider range across countries (from 43.01 for Austria to 71.88 for the UK) than across sectors (from 64.89 for Basic Industries to 70.97 for Energy). Moreover, it can be seen that the financial transparency is no different on average for European firms adopting US GAAP than for those firms that continued to report in accordance with local standards, whilst early IFRS adopters tend to have a lower score. ${ }^{26}$

\footnotetext{
${ }^{26}$ See: http://www2.standardandpoors.com/spf/pdf/fixedincome/Transparency_and_Disclosure_Study_ Europe.pdf. Further details are given in Khanna et al. (2004), who suggest that Standard and Poor's Financial Transparency and Disclosure scores measure disclosure levels against an implicit US rather
} 
The effect of firm level disclosure on the risk premium is tested using a similar methodology to that employed for the examination of accounting transition effects, as follows:

$$
\left(r-r_{f}\right)_{i}=\mu+\alpha_{s}+\beta_{c}+\delta\left[\begin{array}{c}
D_{G A A P} \\
T D_{i} \\
D_{G A A P} \times T D_{i} \\
M C_{i}
\end{array}\right]+\gamma_{t}+e_{i}
$$

where $T D$ is a continuous variable that corresponds to a firm's transparency and disclosure score and $D_{\text {GAAP }}$ is a dummy variable that distinguishes the set of accounting standards applied by the firm, taking the value of 1 if a particular set of standards is followed (local, IFRS or US GAAP) and 0 otherwise. These two variables are further interacted in order to measure the effect of disclosure conditional on the firm's choice of GAAP, and size is also included as a covariate. The relevant main effects and interaction effects are given by the inverse of the vector of coefficients $\boldsymbol{\delta}$. As previously, controls for sector, country, firm and time are also added to the model.

\section{Empirical results}

Panel B of Table 4 sets out the results from regression (12) using the full set of controls. We find that the firm's disclosure scores individually increase the risk premium, as indicated by the positive $\delta$ coefficients on the variable $T D$, which are significant for local accounting standards $(p$-value $=0.025)$, IFRS $(p$-value $<0.001)$ and US GAAP $(p$-value $<0.001)$. This finding corroborates the results reported in Table 3, suggesting that increased transparency adds to the risk premium and that disclosure at a higher standard is costly. However, the incremental effect of the firm's to US disclosure practices rather than providing an absolute measure of disclosure quality. 
disclosure level on the risk premium varies depending on whether a firm follows local standards, IFRS or US GAAP. Following local accounting standards seems to be incrementally costly, as implied by the positive and significant $\delta$ coefficient $(0.0315)$ on the interaction term $D_{G A A P} \times T D$. For firms that prepare their financial statements in accordance with IFRS, the coefficient on $D_{G A A P} \times T D$ is not significantly different from zero, implying that the fact that firms prepare their financial statements in accordance with IFRS neither increases nor reduces the costs of increased disclosure and transparency. On the contrary, for firms that have chosen to adopt US GAAP, the total effect of disclosure is to reduce the risk premium, there being a negative and statistically significant interaction coefficient $(-0.1901) .{ }^{27}$ This result suggests that market participants are ready to pay a premium for firms that commit to more transparent disclosure in accordance with US GAAP (i.e., by reducing the premium demanded for risk). ${ }^{28}$ One possible explanation for this finding is that, in our sample, the majority of firms that adopt US GAAP are cross-listed in the US (around 85\%). ${ }^{29}$ A firm's exposure to SEC enforcement of strict US disclosure requirements signals such commitment to market participants, who are aware of the increased exposure to

\footnotetext{
${ }^{27}$ We have also estimated (12) using the alternative specifications of the risk premium and excluding the control for size effect. The results obtained (not tabulated) are very similar to those reported in Table 4.

${ }^{28}$ Lang, Raedy and Wilson (2004) provide evidence that, among firms cross listed in the US, those that prepare local accounts in accordance with US GAAP show less evidence of earnings management than those that merely reconcile earnings to US GAAP. This is especially the case if the firms are domiciled in jurisdictions offering weak investor protection, suggesting that the extra layer of regulation imposed by the SEC does not replace the effect of the regulatory environment in the firm's country of domicile.

${ }^{29}$ For a cross-listing on a US stock exchange, firms have to file with the SEC, especially if they are to list at the NYSE, thus subjecting themselves to SEC enforcement rules. $67 \%$ of firms from our sample that cross-list in the US are listed at the NYSE, and 18\% are listed on the OTC market.
} 
litigation risks if the firm fails to meet the standards required ${ }^{30}$. In this respect, adopters of IFRS are not on an equal footing.

\section{CONClusions}

This study focuses on the European setting where different GAAP regimes have long been in force, albeit in the presence of gradual harmonization. The economic consequences of such diversity in European accounting stem from the inability of market participants to see through differences in the conservatism bias in financial accounts, which is attributable to the different sets of GAAP in operation. This paper is based on the Abnormal Earnings Growth equity valuation model that describes how the conservatism bias in the forward earnings yield can be corrected by subsequent expected earnings growth.

It is shown empirically that accounting diversity is likely to be of little importance in integrating financial markets. Given this finding, we might expect a similarly inconsequential effect from a switch between standards, or simply a decrease in the risk premium if the firm switches to a higher disclosure regime. However, the switch to internationally recognised GAAP is shown here to entail at least short lived costs, which depend not only on the set of standards adopted but also the level of preadoption disclosure. Further examination of the impact of post-adoption disclosure on

\footnotetext{
${ }^{30}$ Lang, Lins and Miller (2003) demonstrate that firms with ADRs experience increases in valuation around the time of cross listing in the US, which is consistent with these firms enjoying a lower cost of capital. In addition, Leuz and Hail (2004) provide evidence that cross-listing on a US stock market reduces the firm's cost of capital and that this effect is larger for firms domiciled in countries with weaker institutional structures, cross-listing being their way of 'opting out' of the regulatory framework in the country of domicile.
} 
the implied risk premia of firms confirms that the adoption of a more visible set of standards enhances the firm level disclosure effects.

Overall, the findings of this study suggest that accounting diversity per se does not have costs as long as the underlying economies are converging. However, this does not hold in the case of an accounting regime switch, where there are economic consequences which are likely to depend on firm level disclosure efforts around the switch, as well as the standing of the GAAP that are adopted. The more disclosure and the more visible the GAAP, the faster the costs of switching to another set of standards is eliminated. 


\section{REFERENCES}

Abarbanell, J., and R. Lehavy, 'Biased Forecasts or Biased Earnings? The Role of Earnings Management in Explaining Apparent Optimism and Inefficiency in Analysts' Earnings Forecasts', Journal of Accounting and Economics, 36, 2003.

Adjaouté, K., and J.P. Danthine, 'Equity Returns and Integration: Is Europe Changing?’ Oxford Review of Economic Policy, Vol. 20, 2004.

Ball, R., S.P. Kothari and A. Robin, 'The Effect of International Institutional Factors on Properties of Accounting Earnings', Journal of Accounting and Economics, 29, 2000.

Barth, M.E., G. Clinch and T. Shibano, 'International Accounting Harmonization and Global Equity Markets', Journal of Accounting and Economics, 26, 1999.

Basu, S., and S. Markov, 'Loss Function Assumptions in Rational Expectations Tests on Financial Analysts' Earnings Forecasts', Journal of Accounting Economics, 38, 2004.

Beaver, W.H. and S.G. Ryan, 'Conditional and Unconditional Conservatism: Concepts and Modeling', Review of Accounting Studies, 10, 2005.

Botosan, C.A. and M.A. Plumlee, 'A Re-examination of Disclosure Level and the Expected Cost of Equity Capital', Journal of Accounting Research, 40, 2002.

Botosan, C.A. and M.A. Plumlee. 'Assessing Alternative Proxies for the Expected Risk Premium', Accounting Review, 80, 2005.

Botosan, C.A., M.A. Plumlee and Y. Xie, 'The Role of Information Precision in Determining the Cost of Equity Capital', Review of Accounting Studies, 9, 2004.

Bushee, B.J. and C. Leuz, 'Economic Consequences of SEC Disclosure Regulation: Evidence from the OTC Bulletin Board', Journal of Accounting and Economics, 39, 2005.

Bushman, R.M, J.D. Piotroski and A. J. Smith, 'What Determines Corporate Transparency', Journal of Accounting Research, 42, 2004.

Bushman, R., Q. Chen, E. Engel and A. Smith, 'Financial accounting information, organizational complexity and corporate governance systems', Journal of Accounting and Economics, 37, 2004.

Cheng, F., B. Jorgensen and Y.Yoo, 'Implied Cost of Equity Capital in Earnings Based Valuation: International Evidence', Accounting and Business Review, 34, 2004. 
Cuipers, R. and W. Buijink, 'Voluntary Adoption of Non-local GAAP in the European Union: A Study of Determinants and Consequences', European Accounting Review, 14, 2005.

Daske, H., 'Economic Benefits of Adopting IFRS or US-GAAP -- Have the Expected Cost of Equity Capital Really Decreased?', Journal of Business Finance and Accounting, forthcoming

Dechow, P., A. Hutton and R. Sloan, 'The Relation Between Analysts' Forecasts of Long Term Earnings Growth and Stock Price Performance Following Equity Offerings' Contemporary Accounting Research, 17, 2000.

De Bondt, W.F.M. and R. Thaler, 'Do Security Analysts Overreact?', The American Economic Review, 80, 1990.

Easton, P.D., 'PE ratios PEG ratios and Estimating the Implied Expected Rate of Return on Equity Capital', The Accounting Review, 79, 2004.

Estrella, A. and Mishkin F.S, 'The Predictive Power of the Term Structure of Interest Rates in Europe and the United States: Implications for the European Central Bank', European Economic Review, 41, 1997.

Garcia Lara, J.M. and A. Mora, 'Balance Sheet versus Earnings Conservatism in Europe', European Accounting Review, 13, 2004.

Gietzmann, M. and J. Ireland, 'Cost of Capital, Strategic Disclosures and Accounting Choice', Journal of Business Finance and Accounting, 32, 2005.

Giner, B. and W. Rees, 'On the Asymmetric Recognition of Good and Bad News in France Germany and the United Kingdom', Journal of Business Finance and Accounting, 28, 2001.

Gode, D. and P. Mohanram. 'Inferring the Cost of Capital Using the Ohlson-Juettner Model', Review of Accounting Studies, 8, 2003.

Hail, L, 'The impact of voluntary corporate disclosures on the ex-ante cost of capital for Swiss firms', European Accounting Review, 11, 2002.

Helbok, G. and M. Walker, 'On the Nature and Rationality of Analysts' Forecasts Under Earnings Conservatism', British Accounting Review, 36, 2004.

Hong, H. and J.D. Kubik, 'Analyzing the Analysts: Career Concerns and Biased Earnings Forecasts', Journal of Finance, 58, 2003.

Hope, O.K, 'Disclosure Practices, Enforcement of Accounting Standards, and Analysts' Forecast Accuracy: An International Study', Journal of Accounting Research, 41, 2003. 
Hribar, P. and N.T. Jenkins, 'The Effect of Accounting Restatements on Earnings Revisions and the Estimated Cost of Capital', Review of Accounting Studies, 9, 2004.

Irvine, P.J, 'Analysts' Forecasts and Brokerage-Firm Trading', The Accounting Review, 79, 2004.

Khanna, T., K.G. Palepu and S. Srinivasan, 'Disclosure Practices of Foreign Companies Interacting with U.S. Markets', Journal of Accounting Research, 42, 2004.

Land, J. and M.H. Lang, 'Empirical Evidence on the Evolution of International Earnings', Accounting Review, 77, 2002.

Lang, M.H., K.V. Lins and D.P. Miller, 'ADRs, Analysts, and Accuracy: Does CrossListing in the United States Improve a Firm's Information Environment and Increase Market Value?', Journal of Accounting Research, 41, 2003.

Lang, M.H., J.S. Raedy and W. Wilson, Earnings Management and Cross-Listing: Are Reconciled Earnings Comparable to US Earnings?, University of North Carolina Working paper, 2004.

Leuz, C., 'IAS versus U.S. GAAP: Information-Asymmetry-Based Evidence from Germany's New Market', Journal of Accounting Research, 41, 2003.

Leuz, C. and L. Hail, Cost of Capital and Cash Flow Effects of U.S. Cross-Listings, ECGI-Finance Working paper, 2004.

Leuz, C. and L. Hail, International Differences in the Cost of Equity Capital: Do Legal Institutions and Securities Regulation Matter? ECGI-Law Working paper, 2005.

Leuz, C., D. Nanda and P.D. Wysocki, 'Earnings Management and Investor Protection: An International Comparison', Journal of Financial Economics, 69, 2003.

Leuz, C. and R.E. Verrecchia, 'The Economic Consequences of Increased Disclosure', Journal of Accounting Research, 38, 2000.

Levitt, A., 'The Importance of High Quality Accounting Standards', Accounting Horizons, 12, 1998.

Lin, H.W. and M.F. Mcnichols. 'Underwriting Relationships Analysts' Earnings Forecasts and Investment Recommendations', Journal of Accounting and Economics, 25, 1998.

McGregor, W., 'An Insider's View of the Current State and Future Direction of International Accounting Standard Setting', Accounting Horizons, 13, 1999. 
Michael, B.M., B.R. Walther and R.H. Willis, 'Does Forecast Accuracy Matter to Security Analysts?', The Accounting Review, 74, 1999.

Ohlson, J. and B. Juettner-Nauroth, 'Expected EPS and EPS growth as determinants of value', Review of Accounting Studies, 10, 2005.

Piotroski, J.D. and D.T. Roulstone, 'The Influence of Analysts, Institutional Investors, and Insiders on the Incorporation of Market, Industry, and Firm-Specific Information into Stock Prices', Accounting Review, 79, 2004.

Pope, P. and M. Walker, 'International Differences in the Timeliness Conservatism and Classification of Earnings', Journal of Accounting Research, 37, Supplement, 1999.

Raonic, I., S. Mcleay and I. Asimakopoulos, 'The Timeliness of Income Recognition by European Companies: An Analysis of Institutional and Market Complexity', Journal of Business Finance and Accounting, 31, 2004.

Standard and Poor's (S\&P), Transparency and Disclosure Study - Frequently Asked Questions, www.standardandpoors.com, 2002.

Yee, K.K, 'Forward Versus Trailing Earnings in Equity Valuation', Review of Accounting Studies, 9, 2004. 
TABLE 1. Forward Earnings Yield and its Components

Panel A. Medians by country

\begin{tabular}{|c|c|c|c|c|c|c|c|c|c|}
\hline \multirow[b]{2}{*}{ Country } & \multirow[b]{2}{*}{$\begin{array}{l}\text { Number of } \\
\text { observations }\end{array}$} & \multirow[b]{2}{*}{$\begin{array}{c}\text { Forward } \\
\text { earnings } \\
\text { yield }\end{array}$} & \multirow[b]{2}{*}{$\begin{array}{l}\text { Risk } \\
\text { free } \\
\text { rate }\end{array}$} & \multicolumn{2}{|c|}{$\begin{array}{c}\text { Long term growth } \\
\text { = government bond } \\
\text { yield }\end{array}$} & \multicolumn{2}{|c|}{$\begin{array}{l}\text { Long term growth } \\
=\text { future inflation }\end{array}$} & \multicolumn{2}{|c|}{$\begin{array}{c}\text { Long term growth } \\
=0\end{array}$} \\
\hline & & & & $\begin{array}{c}\text { Risk } \\
\text { premium }\end{array}$ & $\begin{array}{c}\text { Abnormal } \\
\text { earnings } \\
\text { yield }\end{array}$ & $\begin{array}{c}\text { Risk } \\
\text { premium }\end{array}$ & $\begin{array}{c}\text { Abnormal } \\
\text { earnings } \\
\text { yield }\end{array}$ & $\begin{array}{c}\text { Risk } \\
\text { premium }\end{array}$ & $\begin{array}{c}\text { Abnormal } \\
\text { earnings } \\
\text { yield }\end{array}$ \\
\hline Austria & 157 & 0.0680 & 0.0586 & 0.0776 & 0.0685 & 0.0671 & 0.0504 & 0.0639 & 0.0445 \\
\hline Belgium & 431 & 0.0703 & 0.0528 & 0.0806 & 0.0613 & 0.0719 & 0.0502 & 0.0676 & 0.0456 \\
\hline Denmark & 480 & 0.0737 & 0.0550 & 0.0743 & 0.0628 & 0.0669 & 0.0509 & 0.0629 & 0.0441 \\
\hline Finland & 584 & 0.0682 & 0.0514 & 0.0966 & 0.0759 & 0.0833 & 0.0607 & 0.0809 & 0.0578 \\
\hline France & 1855 & 0.0649 & 0.0504 & 0.0800 & 0.0664 & 0.0693 & 0.0540 & 0.0657 & 0.0493 \\
\hline Germany & 826 & 0.0548 & 0.0520 & 0.0734 & 0.0711 & 0.0604 & 0.0552 & 0.0568 & 0.0509 \\
\hline Greece & 300 & 0.0585 & 0.0595 & 0.0806 & 0.0898 & 0.0662 & 0.0766 & 0.0566 & 0.0642 \\
\hline Ireland & 99 & 0.0847 & 0.0507 & 0.0779 & 0.0426 & 0.0765 & 0.0395 & 0.0717 & 0.0311 \\
\hline Italy & 860 & 0.0574 & 0.0530 & 0.0789 & 0.0779 & 0.0683 & 0.0638 & 0.0604 & 0.0560 \\
\hline Netherlands & 950 & 0.0885 & 0.0528 & 0.0730 & 0.0421 & 0.0684 & 0.0350 & 0.0668 & 0.0295 \\
\hline Norway & 541 & 0.0713 & 0.0601 & 0.0965 & 0.0811 & 0.0848 & 0.0677 & 0.0805 & 0.0618 \\
\hline Portugal & 228 & 0.0624 & 0.0528 & 0.0782 & 0.0719 & 0.0675 & 0.0602 & 0.0587 & 0.0523 \\
\hline Spain & 664 & 0.0733 & 0.0520 & 0.0742 & 0.0601 & 0.0644 & 0.0499 & 0.0584 & 0.0426 \\
\hline Sweden & 931 & 0.0605 & 0.0524 & 0.0792 & 0.0777 & 0.0663 & 0.0599 & 0.0631 & 0.0562 \\
\hline Switzerland & 368 & 0.0648 & 0.0355 & 0.0845 & 0.0519 & 0.0778 & 0.0433 & 0.0767 & 0.0417 \\
\hline$U K$ & 2121 & 0.0748 & 0.0539 & 0.0706 & 0.0568 & 0.0618 & 0.0459 & 0.0568 & 0.0399 \\
\hline
\end{tabular}


TABLE 1. Forward Earnings Yield and its Components

Panel B. Medians by sector

\begin{tabular}{|c|c|c|c|c|c|c|c|c|c|}
\hline \multirow[b]{2}{*}{ Sector } & \multirow[b]{2}{*}{$\begin{array}{l}\text { Number of } \\
\text { observations }\end{array}$} & \multirow[b]{2}{*}{$\begin{array}{c}\text { Forward } \\
\text { earnings } \\
\text { yield } \\
\end{array}$} & \multirow[b]{2}{*}{$\begin{array}{l}\text { Risk } \\
\text { free } \\
\text { rate }\end{array}$} & \multicolumn{2}{|c|}{$\begin{array}{c}\text { Long term growth } \\
=\text { government bond } \\
\text { yield }\end{array}$} & \multicolumn{2}{|c|}{$\begin{array}{l}\text { Long term growth } \\
=\text { future inflation }\end{array}$} & \multicolumn{2}{|c|}{$\begin{array}{c}\text { Long term growth } \\
=0\end{array}$} \\
\hline & & & & $\begin{array}{c}\text { Risk } \\
\text { premium }\end{array}$ & $\begin{array}{c}\text { Abnormal } \\
\text { earnings } \\
\text { yield }\end{array}$ & $\begin{array}{c}\text { Risk } \\
\text { premium }\end{array}$ & $\begin{array}{c}\text { Abnormal } \\
\text { earnings } \\
\text { yield } \\
\end{array}$ & $\begin{array}{c}\text { Risk } \\
\text { premium }\end{array}$ & $\begin{array}{c}\text { Abnormal } \\
\text { earnings } \\
\text { yield } \\
\end{array}$ \\
\hline Basic industries & 1057 & 0.0812 & 0.0536 & 0.0986 & 0.0726 & 0.0868 & 0.0594 & 0.0833 & 0.0552 \\
\hline Capital goods & 2619 & 0.0779 & 0.0530 & 0.0824 & 0.0617 & 0.0730 & 0.0496 & 0.0699 & 0.0445 \\
\hline Consumer durables & 300 & 0.0919 & 0.0528 & 0.0941 & 0.0569 & 0.0843 & 0.0463 & 0.0821 & 0.0430 \\
\hline Consumer non-durables & 1081 & 0.0733 & 0.0524 & 0.0736 & 0.0544 & 0.0649 & 0.0438 & 0.0618 & 0.0386 \\
\hline Consumer services & 1995 & 0.0595 & 0.0520 & 0.0716 & 0.0669 & 0.0607 & 0.0544 & 0.0558 & 0.0482 \\
\hline Energy & 313 & 0.0701 & 0.0533 & 0.0888 & 0.0700 & 0.0770 & 0.0572 & 0.0729 & 0.0509 \\
\hline Finance & 2021 & 0.0671 & 0.0527 & 0.0678 & 0.0571 & 0.0591 & 0.0453 & 0.0549 & 0.0398 \\
\hline Health care & 426 & 0.0501 & 0.0505 & 0.0602 & 0.0635 & 0.0479 & 0.0502 & 0.0430 & 0.0440 \\
\hline Public Utilities & 343 & 0.0521 & 0.0530 & 0.0558 & 0.0631 & 0.0445 & 0.0475 & 0.0399 & 0.0409 \\
\hline Technology & 822 & 0.0473 & 0.0492 & 0.0946 & 0.0934 & 0.0830 & 0.0800 & 0.0772 & 0.0729 \\
\hline Transportation & 418 & 0.0767 & 0.0550 & 0.0948 & 0.0706 & 0.0827 & 0.0577 & 0.0779 & 0.0531 \\
\hline
\end{tabular}


TABLE 1. Forward Earnings Yield and its Components

Panel C. Medians by year

\begin{tabular}{|c|c|c|c|c|c|c|c|c|c|}
\hline \multirow[b]{2}{*}{ Year } & \multirow[b]{2}{*}{$\begin{array}{l}\text { Number of } \\
\text { observations }\end{array}$} & \multirow[b]{2}{*}{$\begin{array}{l}\text { Forward } \\
\text { earnings } \\
\text { yield }\end{array}$} & \multirow[b]{2}{*}{$\begin{array}{l}\text { Risk } \\
\text { free } \\
\text { rate }\end{array}$} & \multicolumn{2}{|c|}{$\begin{array}{c}\text { Long term growth } \\
=\text { government bond } \\
\text { yield }\end{array}$} & \multicolumn{2}{|c|}{$\begin{array}{l}\text { Long term growth } \\
=\text { future inflation }\end{array}$} & \multicolumn{2}{|c|}{$\begin{array}{c}\text { Long term growth } \\
=0\end{array}$} \\
\hline & & & & $\begin{array}{c}\text { Risk } \\
\text { premium }\end{array}$ & $\begin{array}{l}\text { Abnormal } \\
\text { earnings } \\
\text { yield }\end{array}$ & $\begin{array}{c}\text { Risk } \\
\text { premium }\end{array}$ & $\begin{array}{c}\text { Abnormal } \\
\text { earnings } \\
\text { yield }\end{array}$ & $\begin{array}{c}\text { Risk } \\
\text { premium }\end{array}$ & $\begin{array}{c}\text { Abnormal } \\
\text { earnings } \\
\text { yield }\end{array}$ \\
\hline 1994 & 870 & 0.0678 & 0.0865 & 0.0711 & 0.0902 & 0.0485 & 0.0657 & 0.0426 & 0.0584 \\
\hline 1995 & 977 & 0.0769 & 0.0732 & 0.0718 & 0.0682 & 0.0579 & 0.0503 & 0.0535 & 0.0448 \\
\hline 1996 & 1172 & 0.0659 & 0.0634 & 0.0652 & 0.0677 & 0.0520 & 0.0513 & 0.0474 & 0.0457 \\
\hline 1997 & 1305 & 0.0614 & 0.0558 & 0.0654 & 0.0593 & 0.0544 & 0.0451 & 0.0511 & 0.0413 \\
\hline 1998 & 1349 & 0.0647 & 0.0408 & 0.0762 & 0.0527 & 0.0707 & 0.0455 & 0.0683 & 0.0405 \\
\hline 1999 & 1203 & 0.0632 & 0.0537 & 0.0658 & 0.0620 & 0.0588 & 0.0507 & 0.0532 & 0.0431 \\
\hline 2000 & 1278 & 0.0679 & 0.0504 & 0.0801 & 0.0632 & 0.0726 & 0.0528 & 0.0680 & 0.0463 \\
\hline 2001 & 1149 & 0.0708 & 0.0490 & 0.0897 & 0.0679 & 0.0818 & 0.0594 & 0.0774 & 0.0533 \\
\hline 2002 & 1063 & 0.0862 & 0.0445 & 0.1119 & 0.0698 & 0.1057 & 0.0623 & 0.1008 & 0.0568 \\
\hline 2003 & 1029 & 0.0670 & 0.0435 & 0.0859 & 0.0639 & 0.0782 & 0.0541 & 0.0742 & 0.0500 \\
\hline
\end{tabular}


TABLE 2. Country and Sector Variation

\begin{tabular}{|c|c|c|c|c|c|c|c|c|}
\hline & \multirow[b]{2}{*}{$\begin{array}{l}\text { Degrees of } \\
\text { freedom }\end{array}$} & \multirow[b]{2}{*}{$\begin{array}{l}\text { Forward } \\
\text { earnings } \\
\text { yield }\end{array}$} & \multicolumn{2}{|c|}{$\begin{array}{c}\text { Long term growth } \\
=\text { government bond } \\
\text { yield }\end{array}$} & \multicolumn{2}{|c|}{$\begin{array}{l}\text { Long term growth } \\
=\text { future inflation }\end{array}$} & \multicolumn{2}{|c|}{$\begin{array}{l}\text { Long term growth } \\
=0\end{array}$} \\
\hline & & & $\begin{array}{c}\text { Risk } \\
\text { premium }\end{array}$ & $\begin{array}{l}\text { Abnormal } \\
\text { earnings } \\
\text { yield }\end{array}$ & $\begin{array}{c}\text { Risk } \\
\text { premium }\end{array}$ & $\begin{array}{l}\text { Abnormal } \\
\text { earnings } \\
\text { yield }\end{array}$ & $\begin{array}{c}\text { Risk } \\
\text { premium }\end{array}$ & $\begin{array}{c}\text { Abnormal } \\
\text { earnings } \\
\text { yield }\end{array}$ \\
\hline \multicolumn{9}{|l|}{$1994-2000$} \\
\hline Sector effects $\alpha_{\mathrm{s}}$ & & $16.12 \%$ & $16.52 \%$ & $3.15 \%$ & $18.03 \%$ & $4.17 \%$ & $18.81 \%$ & $4.60 \%$ \\
\hline Country effects $\beta_{\mathrm{c}}$ & & $15.34 \%$ & $14.61 \%$ & $6.10 \%$ & $15.78 \%$ & $5.76 \%$ & $16.56 \%$ & $6.08 \%$ \\
\hline $\begin{array}{l}\text { Sector effects } \alpha_{\mathrm{s}}+\text { country effects } \beta_{\mathrm{c}} \\
\text { Wald } \mathbf{F} \text { test }\end{array}$ & & $20.69 \%$ & $17.56 \%$ & $7.87 \%$ & $19.05 \%$ & $7.76 \%$ & $20.01 \%$ & $8.03 \%$ \\
\hline \multirow[t]{2}{*}{ Joint country effects test } & $\mathrm{F}(15,2456)$ & 16.68 & 4.05 & 18.10 & 3.77 & 13.36 & 4.82 & 12.81 \\
\hline & & $<0.001$ & $<0.001$ & $<0.001$ & $<0.001$ & $<0.001$ & $<0.001$ & $<0.001$ \\
\hline Joint sector effects test & $\begin{array}{l}\mathrm{F}(10,2456) \\
p \text {-value }\end{array}$ & $\begin{array}{r}37.29 \\
<0.001\end{array}$ & $\begin{array}{r}16.77 \\
<0.001\end{array}$ & $\begin{array}{r}7.89 \\
<0.001\end{array}$ & $\begin{array}{r}19.08 \\
<0.001\end{array}$ & $\begin{array}{r}8.48 \\
<0.001\end{array}$ & $\begin{array}{r}20.38 \\
<0.001\end{array}$ & $\begin{array}{r}8.30 \\
<0.001\end{array}$ \\
\hline \multicolumn{9}{|l|}{$2001-2003$} \\
\hline Sector effects $\alpha_{\mathrm{s}}$ & & $13.76 \%$ & $20.76 \%$ & $11.66 \%$ & $21.01 \%$ & $11.76 \%$ & $21.82 \%$ & $12.42 \%$ \\
\hline Country effects $\beta_{\mathrm{c}}$ & & $10.42 \%$ & $19.35 \%$ & $10.49 \%$ & $19.64 \%$ & $10.31 \%$ & $20.34 \%$ & $11.17 \%$ \\
\hline \multicolumn{9}{|l|}{ Wald F test } \\
\hline Joint country effects test & $\mathrm{F}(15,2456)$ & 7.39 & 1.30 & 5.36 & 1.26 & 4.30 & 1.21 & 4.47 \\
\hline & $p$-value & $<0.001$ & 0.254 & $<0.001$ & 0.220 & $<0.001$ & 0.197 & $<0.001$ \\
\hline Joint sector effects test & $\mathrm{F}(10,2456)$ & 22.03 & 5.07 & 11.37 & 5.27 & 10.43 & 5.53 & 9.91 \\
\hline & $p$-value & $<0.001$ & $<0.001$ & $<0.001$ & $<0.001$ & $<0.001$ & $<0.001$ & $<0.001$ \\
\hline
\end{tabular}


Note: The estimated model $\mu+\alpha_{S}+\beta_{c}+\gamma_{t}+M C_{i}+e_{i}$ includes $\alpha_{s}$ sector effects, $\beta_{c}$ country effects and $\gamma_{t}$ time effects. A size control $\left(M C_{i}\right.$, the log of market capitalization in US\$) is also included as a covariate to account for scale effects, and the estimated coefficient ranged between and -0.0041 and -0.0175 . The country and sector effects are not shown in detail, as their computation in STATA's cluster regression is with respect to one particular country or sector that is aliased arbitrarily in the estimation procedure. The joint significance test for the equality of country or sector means allows for the fact that observations are not independent within the same firm, and the appropriate test is therefore a Wald test, with an F distribution. The variance-covariance matrix provides diagnostics at the firm level, and thus the number of degrees of freedom reflects the number of firms and not the number of firm-year observations. 


\section{TABLE 3. Economic Consequences}

Panel A. The economic consequences of accounting transition

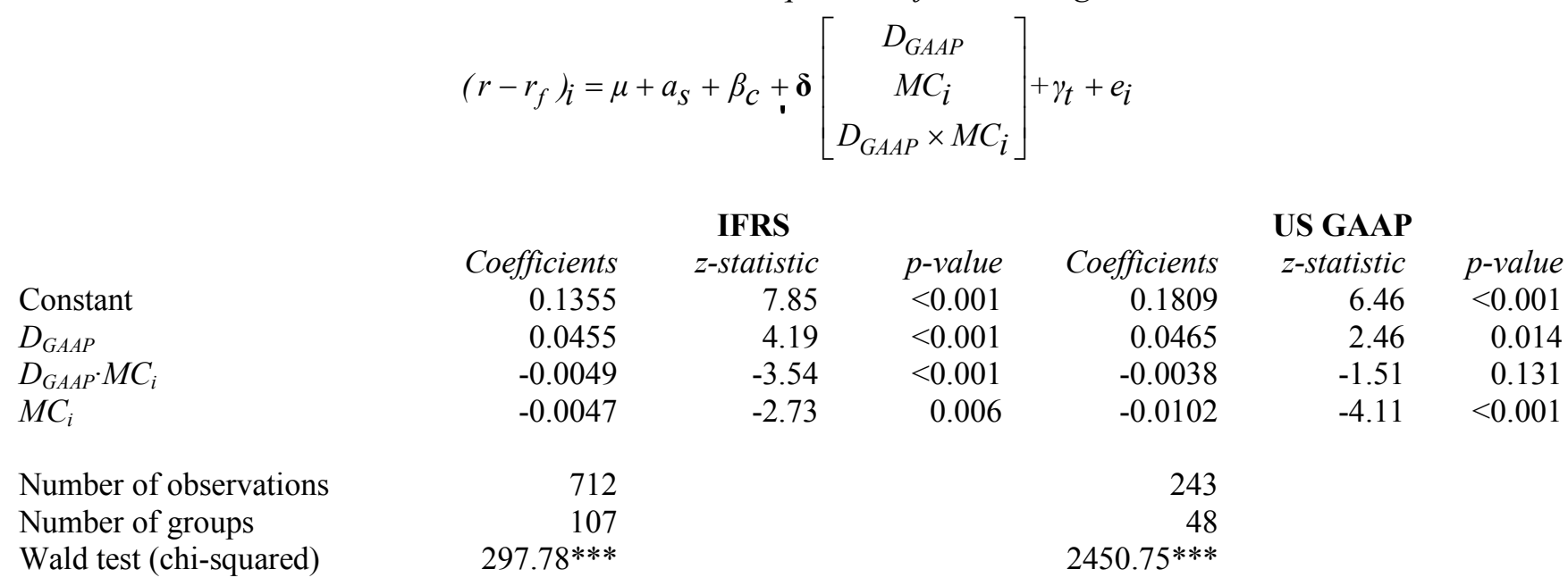

Panel B. The transitory nature of the economic consequences of transition

$$
\left(r-r_{f}\right)_{i}=\mu+a_{S}+\beta_{c}+\lambda\left[\begin{array}{c}
L_{G A A P} \\
M C_{i} \\
L_{G A A P} \times M C_{i}
\end{array}\right]+\gamma_{t}+e_{i}
$$

\begin{tabular}{lrrrr} 
& \multicolumn{3}{c}{ IFRS } \\
& Coefficients & $z$-statistic & $p$-value & Coefficients \\
Constant & 0.2333 & 5.60 & $<0.001$ & 0.0993 \\
$L_{G A A P}$ & -0.0130 & -2.29 & 0.022 & -0.0508 \\
$L_{G A A P} \cdot M C_{i}$ & 0.0019 & 2.84 & 0.005 & 0.0010 \\
$M C_{i}$ & -0.0177 & -8.19 & $<0.001$ & -0.0190 \\
& & & & \\
Number of observations & 307 & & & 90 \\
Number of groups & 81 & & & $3890.10^{* * *}$ \\
Wald test (chi-squared) & $937.18^{* * *}$ & & &
\end{tabular}

US GAAP

z-statistic $\quad$-value

$\begin{array}{rr}1.19 & 0.234 \\ -5.05 & <0.001\end{array}$

$\begin{array}{ll}1.07 & 0.284\end{array}$

$-6.02<0.001$ 
Notes: $(r-r f)_{i}$ is the risk premium of firm $i$ (assuming no long term growth), $\alpha_{s}$ sector effects, $\beta_{c}$ country effects and $\gamma_{t}$ time effects. $\boldsymbol{\delta}^{\prime}$ and $\lambda^{\prime}$ are inverted vectors of parameters on:- $M C_{i}$ the $\log$ of the market capitalization of the $i^{\text {th }}$ firm, $D_{G A A P}$ a dummy variable that takes the value of 1 if a particular set of standards is followed and 0 otherwise, and $L_{G A A P}$ the number of years during which the firm's financial statements have been prepared in accordance with those standards. The constant may be interpreted as the risk premium of a firm with minimum disclosure. The model is estimated by feasible generalized least squares regression in order to control for the presence heteroskedasticity. The Wald test statistic that is reported has a chisquared distribution. 
TABLE 4. Transparency and Disclosure

Panel A. Standard \& Poor's Financial Transparency and Disclosure Scores by Country and by Sector

\begin{tabular}{|lclc|}
\hline Country & Median Score & Sector & Median Score \\
Austria & 43.01 & Basic industries & 64.89 \\
Belgium & 60.64 & Capital goods & 63.83 \\
Denmark & 60.00 & Consumer durables & 68.09 \\
Finland & 75.26 & Consumer non-durables & 61.70 \\
France & 69.52 & Consumer services & 63.27 \\
Germany & 54.88 & Energy & 70.97 \\
Greece & 68.04 & Finance & 64.89 \\
Ireland & 71.88 & Health care & 67.35 \\
Italy & 53.06 & Public Utilities & 64.95 \\
Netherlands & 62.89 & Technology & 67.78 \\
Norway & 49.46 & Transportation & 59.22 \\
Portugal & 54.26 & & \\
Spain & 57.14 & GAAP Regime & \\
Sweden & 61.86 & Local GAAP & 63.75 \\
Switzerland & 63.92 & US GAAP & 64.54 \\
UK & 71.88 & IAS/IFRS & 58.37 \\
\hline
\end{tabular}




\section{TABLE 4. Transparency and Disclosure}

Panel B. Analysis of GAAP Regimes

$$
\left(r-r_{f}\right)_{i}=\mu+\alpha_{s}+\beta_{c}+\boldsymbol{\delta}\left[\begin{array}{c}
D_{G A A P} \\
T D_{i} \\
D_{G A A P} \times T D_{i} \\
M C_{i}
\end{array}\right]+\gamma_{t}+e_{i}
$$

\section{Constant}

$D_{G A A P}$

$T D_{i}$

$D_{G A A P} \cdot T D_{i}$

$M C_{i}$

Number of observations

Number of groups

Wald test (chi-squared)

Coefficients
0.1529
$\underline{-0.0251}$
0.1278

0.0372
$\underline{0.0315}$
0.0687

-0.0112398
1294
254
1941.04

\section{Local GAAP}

z-statistic

10.63

$-2.30$

11.93

2.25

1.83

10.12

$-16.65$

0.000

p-value

$<0.001$

0.021

$<0.001$

0.025

0.067

$<0.001$

$-0.0113941$

1294

254

1943.67
US GAAP

$z$-statistic p-value

12.55

4.15

8.07

$<0.001$

$<0.001$

$<0.001$

$<0.001$

$<0.001$

0.009

0.000 
Notes: $(r-r f)_{i}$ is the risk premium of firm $i$ (assuming no long term growth), $\alpha_{s}$ sector effects, $\beta_{c}$ country effects and $\gamma_{t}$ time effects. $\boldsymbol{\delta}^{\prime}$ is an inverted vector of parameters on:- $M C_{i}$ the $\log$ of the market capitalization of the $i^{\text {th }}$ firm, $D_{G A A P}$ a dummy variable that takes the value of 1 if a particular set of standards is followed and 0 otherwise and $T D_{i}$ the $\mathrm{S} \& \mathrm{P}$ transparency and disclosure score of firm $i$ (scaled by 100 , from 0 to 1 ). The constant may be interpreted as the risk premium of a firm with minimum disclosure. The full sample includes 1294 firm-year observations for those firms for which there is at least one observation of the cost of equity when they were reporting under their local GAAP. The model is estimated by means of a feasible generalized least squares regression in order to control for the presence heteroskedasticity. The Wald test statistic that is reported has a chi-squared distribution. 


\section{FIGURE 1. Abnormal Earnings and Forward Earnings}
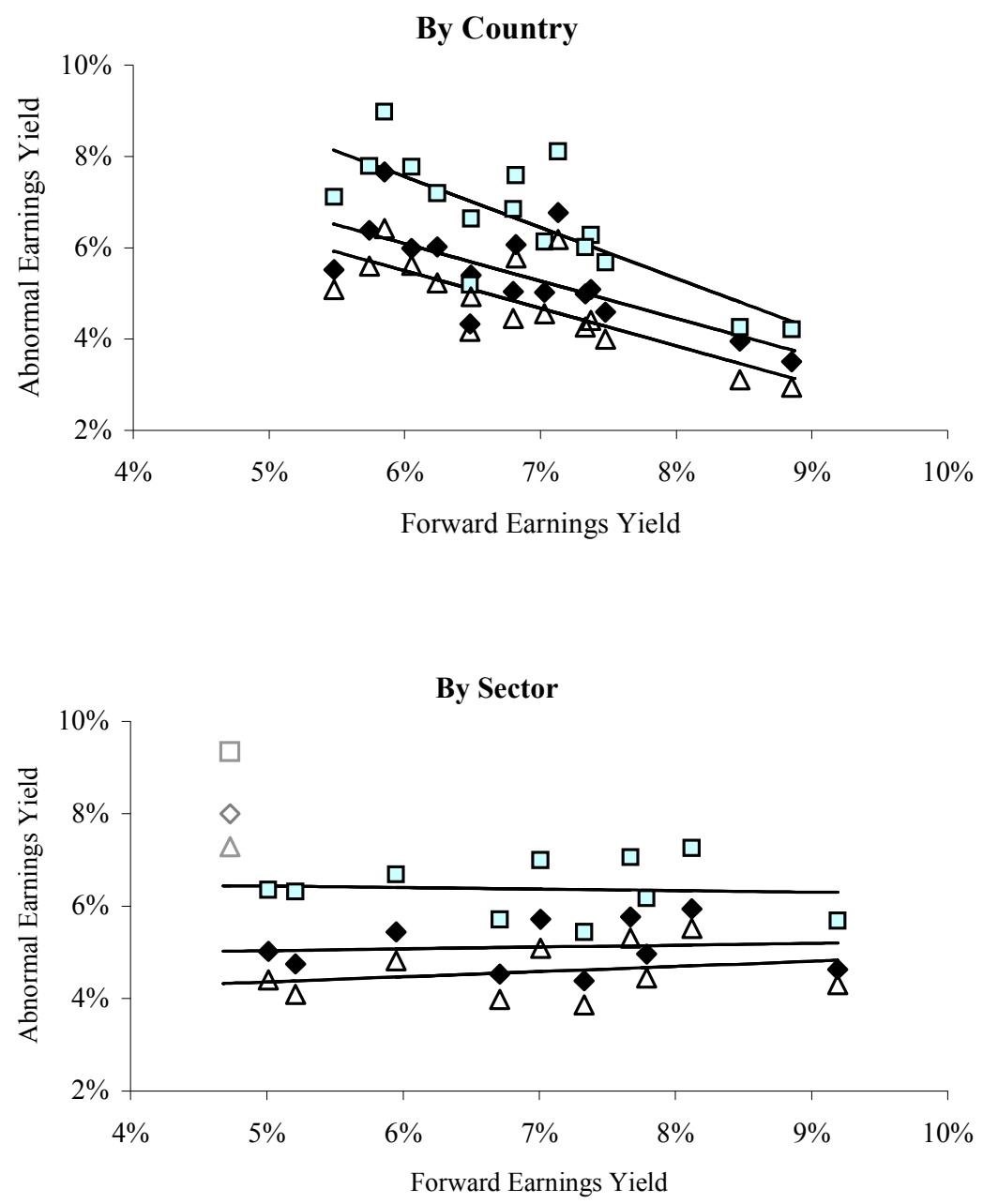

\section{Long term growth ass umptions}

$\square$ government bond yield $\bullet$ inflation $\Delta$ no growth

Note: The indicative slopes have been estimated from the country and sector medians reported in Table 2 for the forward earnings yield and the abnormal earnings yield under each of the three long term growth assumptions. The fitted lines by sector exclude technology, given the unusual circumstances surrounding the internet bubble in the 1990s, the high abnormal earnings yield in that sector being evident at the top left of the graph. 